Debreceni Jogi Múhely 2020. (XVII.) 3-4.

Debreceni Egyetem, Állam- és Jogtudományi Kar, Debrecen

(University of Debrecen, Faculty of Law, Debrecen)

DOI 10.24169/DJM/2020/3-4/2

Boros Sándor

PhD hallgató, Debreceni Egyetem Marton Géza Állam-és Jogtudományi Doktori Iskola ügyvédjelölt

\title{
ÉRTELMEZÉSI ANOMÁLIÁK A BÉCSI VÉTELI EGYEZMÉNY KÁRTÉRÍTÉSI GYAKORLATÁBAN*
}

Debreceni Jogi Múhely, 2020. évi (XVII. évfolyam) 3-4. szám (2020. december 30.)

DOI 10.24169/DJM/2020/3-4/2

Abstract: The essay is about the interpretion anomalies in connection with damages law practice of The United Nations Convention on Contracts for the International Sale of Goods (CISG). This seems to be an essential problem regarding to that the Convention's breach of contract-system is highly relevant, whereas it must provide a mechanism, which serves international trade between countries with huge legal, economic and social disparaties. At the heart of the system we find damages, which provides an efficient and rapid solution to cure the dysfunctions which can occur with respect to cross-border commercial relationships.

The provisions of the Convention are of an universal nature, thus they require uniform interpretation and application by the courts of the Contracting States, therefore Article 7, which deals with interpretation of rules and the filling of legal gaps, is indispensable for the successful application of the Convention and the achievement of its objectives. In this essay by analyzing the relevant case law, I was primarily seeking the answer to whether the judges of different countries validate the universiality of the Convention with respect to damages law. In order to answear the question I have analyzed the Convention's damages practice in relation to interpretation principles set out in Article 7. Within this I have systematically reviewed the practice of Article 74 of the Convention, analyzing a total of 144 cases from 2006 to 2016.

The revision shows that nine decisions were made during the period under review, where the court has applied national doctrine of liability, law, or practice in connection with the interpretation of Article 74 . This method obviously does not promote the realization of uniformity. An internationally uniform sales law will only be realized if it is uniformly applied. For the purpose of the interpretation of the Convention, it follows that requirement the Convention's provisions must be understood and applied autonomously, separated from their possible national roots. The legal problems discovered in this essay tries to highlight on those issues, which require more attention from the courts, thus confirming the universal character of the Convention.

Keywords: CISG, Vienna Convention, breach of contract, damages, punitive damages, good faith, foreseeability doctrine, homeward trend

Absztrakt: A dolgozat az ENSZ, az áruk nemzetközi adásvételi szerződéseiről szóló egyezményének a kártérítési joggyakorlatával kapcsolatos értelmezési anomáliákról szól.

Az Egyezmény rendelkezései univerzális jellegúek, így egységes értelmezést és alkalmazást követelnek meg a részes államok bíróságaitól, ezért a szabályok értelmezésével és a joghézagok kitöltésével foglalkozó 7. Cikk elengedhetetlen az Egyezmény sikeres alkalmazásához. Dolgozatomban a vonatkozó ítélkezési gyakorlat elemzésével, elsősorban arra kerestem választ, hogy a különböző országok ítészei érvényesítik-e az Egyezmény univerzialitását, a kártérités értékelése tekintetében. A kérdés megválaszolása érdekében az Egyezmény kártérítési joggyakorlatát a 7. Cikk által támasztott értelmezési alapelvek relációjában

\footnotetext{
* A tanulmány az Innovációs és Technológiai Minisztérium ÚNKP-19-2 kódszámú Új Nemzeti Kiválóság
} Programjának szakmai támogatásával készült. 
Debreceni Jogi Múhely 2020. (XVII.) 3-4.

Debreceni Egyetem, Állam- és Jogtudományi Kar, Debrecen

(University of Debrecen, Faculty of Law, Debrecen)

DOI 10.24169/DJM/2020/3-4/2

értékeltem. Ennek keretén belül a 74. Cikk joggyakorlatának szisztematikus felülvizsgálatát végeztem el, összesen 144 jogesetet elemezve, a 2006-tól 2016-ig terjedő idôszak tekintetében.

A felülvizsgálat eredménye azt mutatja, hogy kilenc olyan döntés született, amikor a bíróság nemzeti kárfelelősségi doktrínát, jogintézményt, jogszabályt vagy joggyakorlatot alkalmazott a 74. Cikk értelmezése során. Ez a megközelítés nyilvánvalóan nem segíti elő az egységesség megvalósítását. A nemzetközileg egységes szabályozás ugyanis csak akkor valósul meg, ha azt egységesen alkalmazzák. A 7. Cikk által támasztott értemezési követelményekből az következik, hogy az Egyezmény rendelkezéseit autonóm módon, a lehetséges nemzeti felfogástól megkülönböztetve szükséges értelmezni. A dolgozat keretében feltárt jogi problémák azokat a kérdéseket próbálják kiemelni, amelyek nagyobb figyelmet igényelnek a bíróságok részéről, erősítve ezzel az Egyezmény univerzális jellegét.

Kulcsszavak: Bécsi Vételi Egyezmény, szerződésszegés, kártérítés, előreláthatósági doktrína, büntető kártérítés, homeward trend, jóhiszemúség

\section{A Bécsi Vételi Egyezmény}

A gazdasági színtér rendkívüli mértékủ szélesedése az utóbbi évtizedekben megteremtette a globális piacot, mely folyamat a normatív szabályozás oldaláról is globális megközelítést igényelt. Ennek a folyamatnak az eredménye az Egyesült Nemzeteknek az áruk nemzetközi adásvételi szerződéseiről szóló egyezménye, a Bécsi Vételi Egyezmény (United Nations Convention on Contracts for the International Sale of Goods, CISG; továbbiakban: Egyezmény) ${ }^{1}$ lett, mely mind a mai napig a legértékesebb és legnagyobb hatású jogi instrumentumnak minősül az államhatárokon átívelő kereskedelmi ügyletek körében. Az Egyezmény tárgyi hatálya a nemzetközi adásvételre terjed ki, mely jogügylet tradicionálisan a nemzetközi gazdasági kapcsolatok legrégebben kialakult és napjainkig alapvetô formája, ${ }^{2}$ ugyanis a nemzetközi kereskedelemben az áruforgalom döntő hányada ma is adásvételi szerződések alapján bonyolódik le. ${ }^{3}$

Az Egyezmény gyakorlati jelentőségét az adja, hogy szabályai külön kikötés nélkül is alkalmazást nyernek, a hatálya alá tartozó tranzakciók esetében. Jelenleg kilencvenkét ország részese az Egyezménynek, ${ }^{4}$ köztük Nagy Britannia és India kivételével - a világkereskedelem valamennyi szignifikáns résztvevôje, amely nem csak azt jelzi, hogy a gazdasági életben mekkora szerepe van rendelkezéseinek, de széleskörü elfogadottsága arra is rávilágít, hogy az adásvételi jogra vonatkozó szabályokat a részes államok többsége számára kielégítő módon sikerült összegeznie.

Az Egyezmény fontossága alapvetően abban ragadható meg, hogy a jogegységesítés eszközével sikerült a nemzetközi gazdasági kapcsolatok jogában olyan szabályozót alkotni, amely a nemzetközi kereskedelem legfontosabb szerződéstípusának, - azaz a nemzetközi adásvételi szerződésnek - a lényeges nemzetközi elemből adódó sajátosságait megfelelően artikulálja. ${ }^{5}$ Ennek, valamint a fentiekben említett széleskörú elfogadottságának köszönhetően, a nemzetközi gazdaságra gyakorolt hatása elodázhatatlan, pozitív példaként szolgálhat a folyamatban lévő jogegységesítési törekvéseknek.

\section{Az Egyezmény szerződésszegési rendszere}

Az Egyezmény szerződésszegési rezsimje kiemelt relevanciával bír, hiszen védenie kell a stabil és kiszámítható gazdasági környezetet, másrészt a szerződéses felek vagyoni érdekeit. Olyan mechanizmust

\footnotetext{
${ }^{1}$ Kihirdette az 1987. évi 20. törvényerejű rendelet.

2 MolNÁr István János: A nemzetközi gazdasági kapcsolatok joga II- A nemzetközi gazdasági kapcsolatok magánjoga, Patrocinium, Budapest, 2016., 51.

3 BÁNRÉVY Gábor: A nemzetközi gazdasági kapcsolatok joga, 10. javított kiadás, Szent István Társulat, Budapest, 2018., 99.

${ }^{4} \mathrm{Az} \quad$ Egyezményben államok lészes elérhető:

https://treaties.un.org/Pages/ViewDetails.aspx?src=TREATY\&mtdsg_no=X-10\&chapter=10\&clang=_en

${ }^{5}$ VÖRÖS Imre: A nemzetközi gazdasági kapcsolatok joga II., Krim Bt., Budapest, 2015, 84-85.
} 
Debreceni Jogi Múhely 2020. (XVII.) 3-4.

Debreceni Egyetem, Állam- és Jogtudományi Kar, Debrecen

(University of Debrecen, Faculty of Law, Debrecen)

DOI 10.24169/DJM/2020/3-4/2

kell biztosítania, mely kellően érthető és kezelhető, hogy szolgálja az olyan országok közötti nemzetközi kereskedelmet, melyek között óriási jogi, gazdasági és szociális különbségek állnak fenn. Ezzel összhangban az Egyezmény a szerződésszegések körében nem a kontinentális jogban ismert módon szabályoz. ${ }^{6}$ Az Egyezményt megszövegező jogászok a szerződésszegés vonatkozásában a common law egységes szemléletét alkalmazták, ${ }^{7}$ és a rendszer középpontjába a kártérítés jogintézményét helyezték. A szerződésszegésnek ez a koncepciója teljesen idegen a kontinentális jogrendszer felfogásától. ${ }^{8}$ Felismerték, hogy a nemzetközi kereskedelmi viszonyok között megkötött kontraktusok megszegése esetén a jogosultnak lényegesen nagyobb érdeke füződik ahhoz, hogy az árut fedezeti vétel keretén belül a lehető legrövidebb idő alatt beszerezze, így őrizve piaci pozícióját; felmerült kárainak megtérítését pedig a szerződésszegő féltől követelje. ${ }^{9}$ Ennek megfelelően az Egyezmény nem tesz különbséget az egyes szerződésszegési esetek között, és a jogaiban sértett fél szerződésszegés esetén kártérítést lényegében általános jelleggel követelhet, hiszen bármely, a feleket terhelő szerződéses vagy az Egyezmény által elôírt kötelezettség akár kismértékủ megszegése is megalapozza a kártérités iránti igény érvényesítésének lehetőségét. ${ }^{10}$

A kártérítés nem alternatív jogkövetkezményként kerül meghatározásra az Egyezményben, hanem a többi jogkövetkezmény mellett alkalmazható igényként. A fél tehát nem veszíti el a kártérítéshez való jogosultságát pusztán azért, mert a jogsértés orvoslására irányuló egyéb rendelkezésére álló jogait gyakorolja. ${ }^{11}$ Ennek következtében a kártérítés általános jogorvoslati lehetőségként realizálódik a kontraktuális kötelezettségek megszegése esetén.12 Ezzel összhangban az Egyezmény 45. Cikk (1) bekezdés b) pontjában, valamint a 61. Cikk (1) bekezdés b) pontjában foglalt szabályok kártérítési igényt megalapozó, konstitutív normáknak minôsülnek.13 A kártérítés az Egyezmény 28. Cikke ${ }^{14}$ szerint felfogható egyfajta természeti marasztalásként is..$^{15}$

A 74. Cikk a kártérítés mértékét azzal a veszteséggel azonos összegben határozza meg, amely a szerződésszegés következményeként előállt. A kártérítésnek tehát az a jogpolitikai indoka, hogy a jogaiban sértett felet olyan helyzetbe hozza, mintha a másik fél maradéktalanul teljesítette volna a kontraktuális kötelezettségeit. Ugyanakkor a kártérítés mértékének korlátjaként jelentkezik az, hogy csak az olyan károkat kell megtéríteni, amelyek lehetséges bekövetkezését, a szerződéskötés időpontjában, a fél előre látott, vagy látnia kellett volna, az összes körülmények figyelembevételével. ${ }^{16}$

\footnotetext{
${ }^{6}$ VÖRÖS Imre: A nemzetközi gazdasági kapcsolatok joga I., Krim Bt., Budapest, 2015., 21.

7 A common law jellegzetessége, hogy nem differenciál a szerződésszegés különböző formái között, valamint a kártérítést sokkal szélesebb körben alkalmazza, mint a kontinentális jog.

8 VÖRÖS Imre: A nemzetközi gazdasági kapcsolatok joga I., Krim Bt., Budapest, 2015., 21.

9 Boros Sándor: Természetbeni teljesítés vagy kártérítés? Kontinentális és angolszász jogrendszeri válaszok, Debreceni Egyetem Állam- és Jogtudományi Kar, TDK-dolgozat, Debrecen, 2019., 28.

${ }^{10}$ Buschtöns, Corinna: Damages under the CISG: Selected Problems, School of Advanced Law of the University of Cape Town, 2005, 3.

11 MOLNÁR István János: i. m. 78-79.

12 Austria 23 January 2006 Oberlandesgericht [Appellate Court] Linz (Auto case)

13 SÁNDOR Tamás - VÉKÁs Lajos: Nemzetközi Adásvétel: A Bécsi Egyezmény kommentárja, HVG-ORAC Lap- és Könyvkiadó, Budapest, 2005., 275.

14 Egyezmény 28. Cikk: „Ha az Egyezmény rendelkezéseivel összhangban az egyik fél a másik fél valamely kötelezettségének teljesítését jogosult követelni, a bíróság nem köteles természetben marasztalni, kivéve, ha saját joga szerint is így járna el hasonló, az Egyezmény által nem szabályozott adásvételi szerződések esetében.” Ez a rendelkezés az angolszász és a kontinentális jogrendszerek szerződésszegési koncepciója közötti feszültségek feloldására szolgál. Az Egyezmény kodifikátorai a két jogrendszer közötti kompromisszumot a common law-felfogás irányába tett engedménnyel valósították meg, felismerve azt a tényt, hogy a nemzetközi kereskedelmi tranzakciók esetében a felek rendkívül ritkán érdekeltek abban, hogy peres úton kényszerítsék ki a szerződésszegő fél szolgáltatásának teljesítését. A nemzetközi kereskedelemben ugyanis a felek - elsősorban a természetbeni teljesítés kikényszeríthetőségének időbeli elhúzódása miatt - elzárkóznak a teljesítés követelésétől és a kártérítést preferálják, különösen, ha van lehetőség fedezeti szerződés megkötésére.

15 GLAVANITS Judit - RÁCZ Diána: i. m. 16.

16 BÁNRÉvY Gábor: A nemzetközi gazdasági kapcsolatok joga, 10. javított kiadás, Szent István Társulat, Budapest, 2018., 125 .
} 
Debreceni Jogi Múhely 2020. (XVII.) 3-4.

Debreceni Egyetem, Állam- és Jogtudományi Kar, Debrecen

(University of Debrecen, Faculty of Law, Debrecen)

DOI 10.24169/DJM/2020/3-4/2

\section{Esetjogi revízió}

A Bécsi Vételi Egyezmény kodifikációjának elsődleges indoka a nemzetközi adásvételi szerződésekre irányadó joganyag egységesítésére vonatkozó törekvés volt. Ezzel összhangban kardinális szempont az, hogy az egységes jogalkalmazást elősegítendő elvek rögzítésre kerüljenek. ${ }^{17}$ Reális veszélyként mutatkozik ugyanis az, hogy az Egyezmény ugyanazon rendelkezésének alkalmazása során az egyes részes tagállamok bíróságai a saját jogi tradícióik és a saját dogmatikai felfogásuk szerinti interpretációval eltérő eredményre jutva, szétzilálják az egységes jogalkalmazást. ${ }^{18}$

Egy jogszabály tökéletesen egységes értelmezése természetesen olyan idealisztikus állapot, melynek realizálása lehetetlen, ${ }^{19}$ még egyetlen ország joghatósága alatt is. Az ítéleteket ugyanis különböző felfogással, nézetekkel rendelkező bírók hozzák, akik eltérő jogrendszerek szabályain edződtek, továbbá az Egyezménnyel kapcsolatban a nemzeti jogalkalmazó bíróságok felett álló „legfelső” bíróság sem jött létre, amely biztosithatná az egységes értelmezést. Ezért tartalmazza maga az Egyezmény a jogértelmezési szabályt, hogy a bíróságok lehetőleg elkerüljék a nemzeti jogok elveire való hivatkozást. A cél tehát olyan állapot megvalósítása, amelyben az Egyezmény értelmezési gyakorlata összhangban áll a 7. Cikk által támasztott követelményekkel, mely tekintetében a normaszöveg rögzíti az alkalmazandó értelmezési elveket. ${ }^{20}$ Ezeknek az elveknek az elsődleges szerepük, hogy fékezzék a nemzeti bíróságokat, vagy akár a választottbíróságokat, nehogy önkéntelenül is saját jogukhoz forduljanak az Egyezmény alkalmazása során. ${ }^{21}$

Ez azt eredményezi, hogy a bíróságok az Egyezmény hatálya alá tartozó kártérítési jogviták elbírálása során a kártérítés alapvető kérdéseivel foglalkozó 74 . Cikket ${ }^{22}$ a- szabályok értelmezésével és a joghézagok kitöltésével foglalkozó- 7. Cikkel23 összhangban kötelesek alkalmazni. A nemzetközileg egységes kártérítési joggyakorlat megvalósításához elengedhetetlen a 74. és a 7. Cikk harmonikus kölcsönhatása. A 7. Cikk nem csak azt követeli meg a bíróságoktól, hogy a kártérítés értékelése során függetlenítsék magukat a nemzeti kárfelelősségi doktrínáktól, jogintézményektől, elvektôl, hanem azt is, hogy az Egyezményt autonóm módon értelmezve dolgozzák ki az abban rögzített jogintézmények speciális Egyezményjelentését. ${ }^{24}$ Így az egységes jogértelmezést a különböző országok Egyezménnyel kapcsolatos bírói gyakorlata hivatott biztosítani, melynek eredményeként megfigyelhető, hogy egy-egy jogvita elbírálása során valamely peres fél egy külföldi bíróság döntését hívja fel saját tény- vagy jogállításának az igazolására. ${ }^{25}$

Annak megválaszolása érdekében, hogy a bíróságok eleget tesznek-e a 7. Cikk által támasztott értelmezési

\footnotetext{
17 MOLNÁr István János: i. m. 61-62.

18 VÖRÖS Imre: A nemzetközi gazdasági kapcsolatok joga II., Krim Bt., Budapest, 2015, 102.

${ }^{19}$ Honnold, John O.: The Sales Convention in Action - Uniform International Words: Uniform Application? In: Journal of Law and Commerce, 1988., 207-212., 207.

20 SzABÓ Sarolta: Bécsi Vételi Egyezmény, mint nemzetközi lingua franca: Az egységes értelmezés és alkalmazás újabb irányai és eredményei, Pázmány Press, Budapest, 2014. 52.

${ }^{21}$ MÁDL Ferenc - VÉKÁs Lajos: A nemzetközi magánjog és nemzetközi gazdasági kapcsolatok joga, ELTE Eötvös Kiadó, Budapest, 2012., 297.

22 Egyezmény 74. Cikk „A fél szerződésszegése következményeként járó kártérítés összege megegyezik azzal a veszteséggel, amely a szerződésszegés következtében a másik felet érte, ideértve az elmaradt hasznot is. Ez a kártérítés nem haladhatja meg azt a veszteséget, amelyet a szerződésszegő fél a szerződés megkötésének időpontjában előre látott vagy amelyet előre kellett látnia azon tények és körülmények alapján, amelyekről mint a szerződésszegés lehetséges következményeiről az említett időpontban tudott vagy tudnia kellett.”

${ }^{23}$ Egyezmény 7. Cikk (1) „Az Egyezmény értelmezése során figyelembe kell venni annak nemzetközi jellegét és annak szükségességét, hogy elősegítsék az Egyezmény egységes alkalmazását, valamint a jóhiszeműség érvényesítését a nemzetközi kereskedelemben. (2) Az Egyezményben szabályozott ügyekkel összefüggő mindazokat a kérdéseket, amelyekre az Egyezmény kifejezett rendelkezést nem tartalmaz, az Egyezmény alapjául szolgáló általános elvekkel, vagy - ilyen elvek hiányában - a nemzetközi magánjog szabályai alapján alkalmazandó jog rendelkezéseivel összhangban kell megoldani."

${ }^{24}$ Huber, Peter - Muldis, Alastair: The CISG: A New Textbook for Students and Practitioners. Munich: SellierEuropean Law Publishers, Munich, 2007., 7.

25 MOLNÁr István János: i. m. 62.
} 
Debreceni Jogi Múhely 2020. (XVII.) 3-4.

Debreceni Egyetem, Állam- és Jogtudományi Kar, Debrecen

(University of Debrecen, Faculty of Law, Debrecen)

DOI 10.24169/DJM/2020/3-4/2

és alkalmazási követelményeknek, a 74. Cikk esetjogának szisztematikus felülvizsgálatát végeztem el, összesen 144 jogesetet elemezve a 2006-tól 2016-ig terjedő időszak tekintetében. ${ }^{26}$

Álláspontom szerint a téma vonatkozásában végzett esetjogi elemzések által levont következtetések hozzájárulhatnak a joggyakorlat fejlesztéséhez, tekintettel arra, hogy a kártérítés mértékének megállapítása az Egyezmény alkalmazásának nemzetközi szinten is problémás pontja. ${ }^{27}$

Az esetjogi revízió eredménye azt mutatja, hogy a vizsgált 144 bírói döntésből kilenc esetben az eljáró fórum a jogalkalmazása során, figyelmen kívül hagyta az Egyezmény nemzetközi jellegét. Az ezzel kapcsolatban feltárt problémák alapvetően három csoportba sorolhatók. Az első kategóriába tartoznak azok a döntések, melyek a 74. Cikkben rögzített előreláthatósági doktrínát (foreseeability doctrine) analóg módon értelmezik a hazai jogban is megtalálható elöreláthatósági szabállyal (contemplation rule). A második kategória azokat a jogeseteket öleli fel, amikor a bíróság büntető kártérítést (punitive damages) ítélt meg, mely jogintézmény kifejezetten ellentétes az Egyezmény rendelkezéseivel. ${ }^{28}$ Végül a harmadik csoportban azokat a döntéseket találjuk, melyek keretén belül a bíróság részben a nemzeti jog alapján bírálta el a jogvitát, annak ellenére, hogy nem külső joghézagról volt szó. A joghézagok tekintetében ugyanis az Egyezmény differenciál belső és külső joghézag között. Belső joghézag akkor keletkezik, ha az adott jogi kérdés az Egyezményben szabályozott ügyek területén merül fel, de a problémát az Egyezmény kifejezetten nem rendezi. ${ }^{29}$ Ebben az esetben a joghézagok kitöltését a 7. Cikk (2) bekezdése alapján, az Egyezmény általános elvei szerint kell kitölteni. Külső joghézag pedig azon problémák tekintetében keletkezik, amelyeket az Egyezmény kifejezetten kizárt szabályozása köréből. Ezeknek a kérdéseknek az elbírálására mindig nyomban a kollíziós szabályok által kijelölt nemzeti jog lesz az irányadó. ${ }^{30}$ Ebben az esetben jogszerú és egyben indokolt is a nemzeti jog igénybevétele. ${ }^{31}$ Továbbá a harmadik csoportban kerülnek bemutatásra azok a jogesetek is, amelyekben a bíróság az Egyezmény 74. Cikkét kizárólag nemzeti jog alapján elbírált döntéseken keresztül értelmezte.

\section{Az előreláthatósági doktrína}

Az első pontban azokat az eseteket ismertetem, amelyekben a bíróság figyelmen kívül hagyva az Egyezmény nemzetközi karakterét, a szerződéses károk elóreláthatósági doktrínáját analóg módon értelmezte a nemzeti jogi szabállyal. A 74. Cikkben meghatározott előreláthatósági doktrína célja egy olyan mechanizmus biztosítása, mely alapján az Egyezmény hatálya alá tartozó szerződések megszegéséből eredő károk megítélhetôk. Tekintettel arra, hogy a rendelkezés nyilvánvalóan nagy jelentőséggel bír, alapvetó fontosságú, hogy azt a szerződő államok bíróságai és választottbíróságai egységesen értelmezzék. Amennyiben ez nem valósul meg, a felek nem tudnak előre számolni a szerződésszegés következményeként érvényesíthető jogosultságaikkal, ${ }^{32}$ amely nagymértékú jogbizonytalanságot okozhat a nemzetközi kereskedelem területén.

A TeeVee Tunes, Inc. et al v. Gerbard Schubert GmbH ${ }^{33}$ ügyben a felperes - többek között - kártérítés iránti igényt terjesztett elő egy olyan szerződés megszegése miatt, mely alapján az alperes környezetbarát audióés videókazetta borító előállitásához szükséges csomagolási rendszer szolgáltatására volt köteles. A

\footnotetext{
${ }^{26}$ A jogesetek elérhetőek: http://www.cisg.law.pace.edu/cisg/text/digest-cases-74.html

27 GLAVANITS Judit: A Bécsi Egyezmény magyar és nemzetközi joggyakorlata - kérdések és kétségek között In: Glavanits Judit (szerk.): A nemzetközi adásvételi szerződések joggyakorlatának aktuális kérdései, SZIE - Deák Ferenc Állam- és Jogtudományi Kar, Győr, (2017) 17.

${ }^{28}$ CISG Advisory Council Opinion No. 6: Calculation of Damages under CISG Article 74

${ }^{29}$ Efstathiou, Stefania: How internal and external gaps within the CISG are to be filled and an opinion on the approach taken by Art. 7. para 2 CISG, 6 .

30 SÁNDOR Tamás - VÉKÁs Lajos: Nemzetközi Adásvétel: A Bécsi Egyezmény kommentárja, HVG-ORAC Lap- és Könyvkiadó, Budapest, (2005) 75-76.

31 Hayward, Benjamin - Perlen, Patricia: The CISG in Australia - The Jigsaw Puzzle That Doesn't Quite Fit, Vindobona journal of international commercial law and arbitration, vol. 15., no. 1. pp. 119-156., (2011) 129.

32 EHLERS, Andreas: Establishing a Uniform Interpretation of the CISG: A Case Study of Article 74, (2013) NJCL [v] 17-18.

33 United States 23 August 2006 Federal District Court [New York] (TeeVee Tunes, Inc. et al v. Gerbard Schubert GmbH)
} 
Debreceni Jogi Múhely 2020. (XVII.) 3-4.

Debreceni Egyetem, Állam- és Jogtudományi Kar, Debrecen

(University of Debrecen, Faculty of Law, Debrecen)

DOI 10.24169/DJM/2020/3-4/2

teljesítés után azonban nyilvánvalóvá vált, hogy a rendszer súlyos rendellenességeket produkál múködése során. A vevő azt állította, hogy a hiba következményeként több millió dollár kárt szenvedett el, mely magában foglalja a javítási költségeket, a műszaki szakemberek munkadíját, a meghibásodott alkatrészek cseréjét, a csomagolási rendszer működtetése érdekében felállított létesítmény építési költségeit, valamint az adminisztrációs díjakat és az elmaradt hasznot. A vevő által elszenvedett károk elöreláthatóságával kapcsolatos érvelésében a bíróság kijelentette, hogy az Egyezmény 74. Cikke által rögzített előreláthatósági követelmény megegyezik a Hadley v. Baxendale 34 ügy közismert szabályával. A két doktrína „összemosása” azonban már egy korábbi ítéletben is megfigyelhető, melyre az ügyben eljáró fórum is hivatkozik a 74. Cikk értelmezése során. A Delchi Carrier, S.p.A. v Rotorex Corp. ügyben ${ }^{35}$ a bíróság a Hadley - szabályra utalva rögzítette, hogy a 74. Cikkben foglalt rendelkezés célja, hogy a ,jogaiban sértett felet ugyanolyan jó belyzetbe hozza, mintha a másile fél megfelelöen teljesitette volna a szerröódést".

Az előreláthatósági doktrína hasonló értelmezése figyelhető meg a CITGO Petroleum Corp. v. Odfjell Seachem ügyben is. ${ }^{36} \mathrm{~A}$ jogvitát megelőzően az I. rendű alperes, az YPF argentin olajipari társaság nagy mennyiségú ciklohexánt értékesített a Tricon energetikai vállalatnak, több mint négy millió dollár értékben. Ezt követően az I. r. alperes megállapodott a II. rendủ alperessel, az Odfjell Seachem, vegyi anyagok szállitására specializálódott norvég hajózási társasággal abban, hogy az árut a Bow Fighter típusú hajójának fedélzetén, 2005. március 15-ig a texasi Houstonba szállítja. A szerződés kimondta, hogy az eladó az árut CFR alapján szállítja, amely a költség és teher (cost and freight) nemzetközi kereskedelemben használt szabványkódja, mely azt jelenti, hogy az eladó gondoskodik a szállítás megszervezéséről, és viseli annak költségeit. Azonban amint az áru a hajóra kerül, a veszteség kockázata a vevőre száll. A Tricon viszont adásvételi szerződést kötött a Citgo olajipari vállalattal, a megvásárolt ciklohexán továbbértékesítése tekintetében. A Tricon vállalta, hogy az árut a Bow Fighter hajó fedélzetén, 2005. április 20-ig a texasi Freeportba szállítja. A hajó a motor meghibásodása miatt közel két hónap késéssel érkezett a houstoni, majd a freeporti kikötőbe. A Tricon ezért kénytelen volt beszerezni a ciklohexánt magasabb áron egy másik piaci szereplőtől fedezeti vétel keretén belül. A Citgo azonban ennek köszönhetően később szállította az árut vevőjének, jelentős károkat elszenvedve így. Ezt követően a Citgo és a Tricon engedményezési szerződést kötöttek egymással, mely alapján a Tricon az üggyel kapcsolatos valamennyi igénye érvényesítésének jogát a Citgo-ra ruházta, az elszenvedett károk megtérítése tekintetében is. A Citgo keresetlevelet nyújtott be a Tricon nevében, mint annak engedményese, valamint a saját nevében is, melyben többek között azt állitotta, hogy az I. r. alperes megszegte az Egyezmény 32. Cikkét, mivel nem gondoskodott megfelelően az áru szállításáról. Az YPF társaság azzal védekezett, hogy a károk bekövetkezése nem volt előrelátható a szerződés megkötésének időpontjában. Ezzel szemben a felperes azzal érvelt, hogy a károk felmerülése előrelátható volt, mivel az alperes tudta, vagy tudnia kellett, hogy a Tricon viszonteladással foglalkozott. Az alperes ellenérvelésében nagymértékben támaszkodott a Hadley szabályra. A bíróság döntésében hosszasan foglalkozott a kérdéssel, a 74. Cikkben rögzített előreláthatósági klauzulát azonban kizárólag nemzeti jogesetek figyelembevételével értelmezte. A bíróság indokolásában a texasi Legfelsőbb Bíróság döntése ${ }^{37}$ nyomán előadta, hogy a Hadley v. Baxendale ügy irányadó a szerződéses károk előreláthatóságával kapcsolatban. Továbbá citálta azt a döntést is, ${ }^{38}$ melyben a bíróság rögzítette, hogy a szabály csaknem univerzális jellegűvé vált. Az utóbbi jogeset analógiájára a bíróság végül megállapította, hogy a károk akkor lettek volna előreláthatók az eladó számára, ha a tudomására hozták volna, hogy szerződéses partnere viszonteladó, nem pedig olyan vállalat, amely a maga számára vásárolja és használja a ciklohexánt és hogy a Tricon rövid távú szerződéseket kötött annak továbbértékesítésére. A felperes nem tett eleget bizonyítási kötelezettségének a tekintetben, hogy az alperes birtokában volt-e ezeknek az információknak, ezért a bíróság a felperes kereseti kérelmét elutasította.

A 74. Cikk által rögzített előreláthatósági doktrína azonosítása a Hadley - szabállyal problematikus, mivel

\footnotetext{
${ }^{34}$ Hadley v. Baxendale (1854) 9 Ex. 341

35 United States 6 December 1995 Federal Appellate Court [2nd Circuit] (Delchi Carrier v. Rotorex)

36 United States 10 December 2014 Federal District Court [Texas] (CITGO Petroleum Corp. v. Odfjell Seachem)

${ }^{37}$ Mead v. Johnson Group, Inc., 615 S.W.2d 685 (Tex. 1981)

${ }^{38}$ Hector Martinez \& Co. v. S. Pac. Transp. Co. 606 F.2d 106 (5th Cir. 1979)
} 
Debreceni Jogi Múhely 2020. (XVII.) 3-4.

Debreceni Egyetem, Állam- és Jogtudományi Kar, Debrecen

(University of Debrecen, Faculty of Law, Debrecen)

DOI 10.24169/DJM/2020/3-4/2

az utóbbi egyáltalán nem áll összhangban az Egyezmény rendelkezésével. ${ }^{39}$ Bár a doktrínát egyértelmúen az angol és amerikai bírói gyakorlat fejlesztette, lényeges különbségek figyelhetôk meg a common law által alkalmazott előreláthatósági korlát (contemplation rule) és az Egyezményben rögzített előreláthatósági doktrína (foreseeability doctrine) között. ${ }^{40} \mathrm{~A}$ common law ugyanis a szabályt a megítélhető károk felső korlátjaként kezeli, oly módon, hogy leszúkíti azokat azon károkra, amelyekre a felek a szerződéskötéskor, mint a szerződésszegés valószínú következményeire gondolhattak. Az angolszász joggyakorlatban ezzel kapcsolatban megfigyelhető az a tendencia, hogy a bíróságok nem ítélik meg azokat a károkat, amelyeket nagy valószínűséggel nem lehetett előre jelezni a szerződéskötéskor. Ezzel ellentétben az Egyezmény a kártéritési felelősséget azokra a károkra korlátozza, melyeket a szerződésszegő fél a szerződés megkötésének időpontjában előre látott, vagy amelyeket előre kellett látnia. A károk megítéléséhez elegendő, ha a szerződésszegő fél előre kalkulálhatott a kárral, mint a szerződésszegés lehetséges következményével. ${ }^{41} \mathrm{Az}$ előreláthatósági doktrína célja tehát az, hogy a szokatlan, előre nem látható rendkívüli, és az így nem is kalkulálható károk megtérítését kizárja. ${ }^{42}$ Tisztán látható, hogy az Egyezmény által rögzített szabály a megítélhető károk tekintetében egy lényegesen tágabb megoldást alkalmaz, mely szélesebb diszkrecionális jogkört biztosít a bíróságok számára. A 74. Cikk ugyanis lehetséges következményként határozza meg a megítélhetô károk körét, míg a common law a szerződéses károk előreláthatóságával kapcsolatban valószínűséget követel meg, amely nagyobb fokú ismereteket igényel a felek részéről. Az Egyezmény így kiszélesíti a kártéritési felelősség körét a szerződésszegő fél esetén. ${ }^{43}$

A két előreláthatósági szabály egymással történő azonosítása a feltárt különbségekből fakadó feszültségek következtében kerülendő a bíróságok részéről. A 74. Cikkben foglalt előreláthatósági doktrínának ugyanis az Egyezmény 7. Cikke alapján speciális Egyezmény-jelentéssel kell bírnia, mely megköveteli a bírótól az Egyezmény nemzetközi jellegének figyelembevételét, azaz, hogy a nemzetközi szöveget ne a nemzeti jog lencséjén keresztül olvassa, ${ }^{44}$ az Egyezményt ugyanis saját szabályaiból, per se kell értelmezni.

\section{Büntető kártérítés}

Az alábbiakban ismertetésre kerülnek azok a jogesetek, amelyekben az eljáró fórum valamely peres fél kérelmére büntető kártérítést ítélt meg, annak ellenére, hogy a jogintézmény alkalmazása ellentétben áll az Egyezmény szellemiségével. Napjainkban a büntető kártérités olyan, a rendes kártérítés mértékén felül is kiszabható összeg, amelyet a károkozó a károsultnak köteles megfizetni, és amelynek elsődleges funkciója nem a sértett kompenzációja, hanem a károkozó büntetése, és a jövőben a hasonló magatartás tanúsításától való elrettentése. A büntető kártérítést exemplary damages néven 'kitaláló' angolok a jogintézménytől egyébként már megszabadultak, és az USA a punitive damages koncepciót a szerződési jogban alapvetôen nem alkalmazza, az ugyanis a tort law sajátja.

A Gunagxi v. Long River ügyben ${ }^{45}$ a felek a jogvitát megelőzően számos adásvételi szerződést kötöttek egymással, melyeknek tárgya fagyasztott tilápia filé volt. A kontraktus értelmében a felperes kötelezettséget vállalt arra, hogy az árut hajón eljuttatja az alperes által megjelölt amerikai kikötőkbe. Az eladó az árut határidőben szállította, majd megküldte az alperes részére a szállitás költségeiről kiállított számlákat. Bár a

${ }^{39}$ Ferrari, Franco: Comparative Ruminations on the Foreseeability of Damages in Contract Law, 53 La. L. Rev. (1993) 1268.; MurPheY, Arthur: Consequential Damages in Contracts for the International Sale of Goods and the Legacy of Hadley, 23 Geo. Wash. J. Int'l L. \& Econ. 415 (1989-1990) 417.

${ }^{40}$ VÉKÁs Lajos: The Foreseeability Doctrine in Contractual Damage Cases In: Acta Juridica Hungarica 43, Nos 1-2, pp. 145-174 (2002) 159.

41 VÉKÁs Lajos: i. m. 159-160.

42 CSÉCSY Andrea: A szerződésszegés jogkövetkezményeinek magyar és külföldi összehasonlító jogi elemzése, PhD értekezés, Miskolci Egyetem Állam- és Jogtudományi Kar, Deák Ferenc Állam- és Jogtudományi Doktori Iskola, Miskolc, 2008., 182.

${ }^{43}$ MurPHeY, Arthur: Consequential Damages in Contracts for the International Sale of Goods and the Legacy of Hadley, 23 Geo. Wash. J. Int'l L. \& Econ. 415 (1989-1990) 440.

${ }^{44}$ Honnold, John O.: The Sales Convention in Action - Uniform International Words: Uniform Application? In: Journal of Law and Commerce, 1988., 207-212., 208.

${ }^{45}$ United States 30 March 2010 Federal District Court [New York] (Guangxi Nanning Baiyang Food Co. Ltd. v. Long River International, Inc.) 
Debreceni Jogi Múhely 2020. (XVII.) 3-4.

Debreceni Egyetem, Állam- és Jogtudományi Kar, Debrecen

(University of Debrecen, Faculty of Law, Debrecen)

DOI 10.24169/DJM/2020/3-4/2

vevő benyújtotta az amerikai hatóságok felé a vámnyilatkozatát, de az áru átvételét vagy az eladónak történő fizetést magyarázat nélkül megtagadta. Ennek következtében az amerikai vámügyi hatóság visszatartotta az áru kiadását mindaddig, míg a vevő hivatalos levelében vissza nem utasítja annak átvételét. A következő hetekben a felperes számos alkalommal megkísérelte felvenni a kapcsolatot a vevôvel, sikertelenül. Végül több mint két hét késéssel az alperes megküldte az áru átvételének megtagadását tartalmazó levelét, így a felperes továbbértékesíthette azt egy másik piaci szereplőnek. A késedelemnek köszönhetően az eladó jelentős károkat szenvedett el. A hal értéke ugyanis a konténerekben történő huzamos idejű tárolás miatti minőségi romlásnak köszönhetően nagymértékben csökkent, valamint a felperes kénytelen volt bérleti dijat is fizetni a konténerek után. Az eladó peren kívüli egyezség megkötése útján kívánta rendezni a vitát, így panaszát megküldte a vevőnek, az alperes közel hat hetet késett a válaszadással. Az eladó a válasz megérkezését megelőzően pár nappal kereseti kérelmet nyújtott be a bírósághoz, melyben ténylegesen felmerült kárának megtérítése mellett, büntető kártérítés iránti igényt is előterjesztett, 500.000 dollár értékben. Utóbbit arra alapozta, hogy a vevő késlekedett a panaszra történő válaszadással. A bíróság helyt adott a felperes kereseti kérelmének. Indokolásában előadta, hogy a büntető kártérítésről az Egyezmény egyáltalán nem rendelkezik, így külső joghézagról van szó, melyet az Egyezmény 7. Cikk (2) bekezdése szerint a kollíziós szabályok által kijelölt nemzeti jog rendelkezései szerint kell kitölteni.

Hasonló probléma figyelhető meg az Al Hewar v. Southeast Ranch ${ }^{46}$ ügyben is. A felek széna adásvételéről rendelkező szerződést kötöttek egymással. A vevő mezőgazdasági termékek forgalmazásával foglalkozott az Egyesült Arab Emirátusok területén, az eladó pedig amerikai vállalatként tevékenykedett ugyanabban a piaci szektorban. A vevő a több mint másfél millió dolláros vételár kiegyenlítése érdekében hitelszerződést kötött egy helyi bankkal, valamint adásvételi szerződést kötött Abu Dhabi kormányával az áru továbbértékesítése tekintetében. A széna nem érkezett meg a vevőhöz, aki kénytelen volt felmondani a kormánnyal kötött szerződést, melynek hatására az megtagadta a jövőbeni üzleti együttmúködést a felperessel. Ezeken túlmenően a vevő az eladó nem teljesítése miatt a banki hitel refinanszírozása során is mulasztott. A vevő pert indított, melyben kérte teljes kárának megtérítését, valamint büntető kártérítés iránti igényt is előterjesztett. Az utóbbit arra alapozta, hogy az alperes a szerződés megkötésével kapcsolatos tárgyalások során tudatában volt annak, hogy olyan hamis kijelentéseket tesz, amelyek lényegesen befolyásolják a felperes magatartását. A vevő ugyanis ezen állítások hatására kötötte meg a hitel- és a továbbértékesítési szerződést is. A bíróság helyt adott a kereseti kérelmének, így az Egyezmény 74. Cikke alapján meghatározott tényleges károk mellett, 500.000 dollár büntető kártérítést is megítélt. Indokolásában előadta, hogy az alperesi magatartás csalárd megtévesztésnek minősül (fraudulent inducement), mely a floridai jog alapján önálló kártérítési alakzat, elkülönül a kontraktuális kártérítési felelősségtől, így a két igény egyidejủleg, párhuzamosan is érvényesíthető. Érvelését a bíróság nemzeti jogesetekkel támasztotta alá.

Az Egyezmény a büntető kártérítés megfizetésének kérdését nem rendezi, ez azonban nem jelenti azt, hogy külső joghézagról lenne szó, melyet a kollíziós szabályok által kijelölt nemzeti jog figyelembevételével kellene elbírálni. A jogintézmény alkalmazása ugyanis ellentétes a 74. Cikk által megállapított szabállyal, mely szerint a kártérítés csak korlátozott összegủ lehet. ${ }^{47}$ A büntető kártérítés esetén a megítélt összeg meghaladja a tényleges vagy névleges kártérítést, a célból, hogy a másik fél sértő, rosszhiszemú magatartását megtorolják. Az ilyen kártérítés azért nem ítélhető meg, mert a 74. Cikk alapján a kártérítés összege „megegyezile azzal a veszteséggel, amely a szerződésszegés következtében a másik felet érte, ideértve az elmaradt hasznot is". Az Egyezmény abban az esetben is kizárja a büntető kártérítést, ha a nemzeti jog azt lehetővé teszi a szerződés megszegése esetén. Ugyanakkor a felek megállapodásukkal lehetôvé tehetik a rendes vagy választottbíróság számára az alkalmazandó jog által megengedett mértékben a büntetó kártérítés megítélését.48 A bemutatott jogesetek vonatkozásában a felek között megkötött szerződések ilyen kikötést nem tartalmaztak. A bíróságoknak hangsúlyt kell fektetniük a büntető kártérítés jogszerű alkalmazására,

\footnotetext{
46 United States 7 November 2011 Federal District Court [Florida] (Al Hewar Enviromental \& Public Health Establishment v. Southeast Ranch, LLC and Joel Gutierre)

${ }^{47}$ SZABÓ Sarolta: A Bécsi Vételi Egyezmény, mint nemzetközi lingua franca: Az egységes értelmezés és alkalmazás újabb irányai és eredményei, Pázmány Press, Budapest, 2014. 204.

${ }^{48}$ CISG Advisory Council Opinion No. 6: Calculation of Damages under CISG Article 74
} 
Debreceni Jogi Múhely 2020. (XVII.) 3-4.

Debreceni Egyetem, Állam- és Jogtudományi Kar, Debrecen

(University of Debrecen, Faculty of Law, Debrecen)

DOI 10.24169/DJM/2020/3-4/2

annak érdekében, hogy az itélkezési gyakorlat megfeleljen az Egyezmény szabályrendszerének. ${ }^{49}$ Helyesen mutat rá az Egyezmény és a kizárólag az állami jogra alapított kártérítési igény viszonyára a Sky Cast $v$. Global Direct ügyben ${ }^{50}$ hozott döntés. A jogvitában az alperes gondatlan megtévesztésre (negligent misrepresentation) hivatkozva az állami jogra alapította kártérítési igényét, előadva azt, hogy számára a felperes hamis információkat nyújtott, melynek következtében károkat szenvedett el. A bíróság ítéletében rögzítette, hogy „az alperes igénye tisztán kártéritési igény, amely teljesen különbözile a kontraktuális igényektól. A biróság igy arra a következtetésre jutott, bogy azt a CISG nem szabályozza, mivel az. Egyezmény csak az ingó dolgok. adásvételével foglalkozilk a különbözó országokban található kereskedök között, igy a gondatlan megtévesztésre alapitott kártéritési igény elbirálása az állami jogra tartozik". Ennek megfelelően az alperes erre vonatkozó kérelme elutasitásra került. Szintén az Egyezmény szabályainak megfelelő döntés született az athéni bíróság 4505/2009. számú ügyében ${ }^{51}$ is. A fórum rögzítette, hogy alaptalan az alperes erkölcsi károk megtérítése iránt előterjesztett igénye, tekintettel arra, hogy a „nem-vagyoni károk megtéritése az Egyezmény szabályozási körén kivül esik, igy azoke nem orvosolhatóak".

\section{Homeward trend - törekvés a nemzeti jog alkalmazása iránt}

Az alábbi pontban ismertetem azokat a jogeseteket, amelyekben a bíróság nemzeti jogi rendelkezéseket vagy nemzeti jogeseteket alkalmazott a jogvita elbírálása során, annak ellenére, hogy a felmerült kérdés az Egyezmény hatálya alá tartozott.

A Svájci Fellebbviteli Bíróság BZ.2007.55 számú ügyében ${ }^{52}$ a felek adásvételi szerződést kötöttek egymással, melynek tárgya nagy mennyiségú hólánc volt. A megállapodás értelmében, a vevő kötelezettséget vállalt arra, hogy az árut kizárólag a felek által meghatározott országban értékesíti tovább. A vevő azonban abban az országban értékesítette a hóláncokat, amelyben az eladó az áru tekintetében piaci érdekeltséggel rendelkezett, ezért az eladó megtagadta a vevő által már megrendelt, és előre kifizetett áru szállítását. A vevő így elállt a szerződéstől, és pert indított az eladóval szemben, melynek keretén belül követelte a vételár visszatérítését, valamint az elmaradt haszon formájában jelentkező kárának a megtérítését. Az alperes ellenkérelmében kérte a bíróságtól a felperes kérelmének elutasítását, és viszontkeresetként a svájci Kötelmi Jogi Törvénykönyv 41. Cikke és a culpa in contrahendo ${ }^{53}$ felelősségi alakzat alapján követelte kárai megtérítését. Érvelésében előadta, hogy a felperes a szerződéskötést megelőző tárgyalások alatt vállalt kötelezettségét megszegte, azáltal, hogy olyan országban értékesítette az árut, amelyben üzleti érdekeltséggel rendelkezett az eladó. A bíróság alaposnak találta az alperesi viszontkeresetet, és annak jogalapját sem kifogásolta. Indokolásában rögzítette, hogy a vevő a tárgyalási folyamat alatt "olyan negatív tartalmú kötelezettséget vállalt, amelyet másodlagos kontraktuális kötelezeltségként kell értékelni." Döntését a fórum nemzeti jogesetek és a vonatkozó hazai jogirodalom hivatkozásával támasztotta alá. A bíróság jogalkalmazása azonban ellentétes volt az Egyezmény koncepciójával, ugyanis az Egyezmény megalkotásának egyik elsődleges célja az volt, hogy megkönnyítse a nemzetközi tranzakciók lebonyolítását azáltal, hogy kiküszöböli a különböző országok jogrendszere által támasztott eltérő szerződéses kötelezettségekből eredő bizonytalanságot. ${ }^{54}$

Az Egyezmény a prekontraktuális felelősség kérdését nem rendezi, azonban ez nem jelenti azt, hogy az ezzel kapcsolatos kártérítési igények az Egyezmény szabályozási körén kívül esnének, külső joghézagot keletkeztetve. Továbbá az Egyezmény „hallgatása” nem eredményezheti az e tekintetben alapított igények merev elutasítását sem. Így nem helytálló a Német Legfelsőbb Bíróság döntése, ${ }^{55}$ melyben elutasították a

\footnotetext{
${ }^{49}$ KIrby, Amy A.: Punitive Damages in Contract Actions: The Tension between the United Nations Convention on Contracts for the International Sale of Goods and U. S. Law, 16 J. L. \& Com. 215 (1997) 217.

${ }^{50}$ United States 18 March 2008 Federal District Court [Kentucky] (Sky Cast, Inc. v. Global Direct Distribution, LLC)

51 Greece 2009 Decision 4505/2009 of the Multi-Member Court of First Instance of Athens (Bullet-proof vest case)

52 Switzerland 13 May 2008 Appellate Court St. Gallen (Skid chains and adaptors case)

${ }^{53} \mathrm{Az}$ elv lényege, hogy a szerződő felek kötelesek jóhiszeműen cselekedni a tárgyalások során. Az a fél, aki ennek a kötelezettségnek nem tesz eleget, felelős a másik fél ebből eredő kárainak a megtérítéséért.

54 KLEIN, John - BACHECHI, Carla: Precontractual Liability and the Duty of Good Faith Negotiations in International Transactions, 17 Hous. J. Int'l L. 1 (1994) 3.

55 Germany 26 September 2012 Supreme Court (Clay case)
} 
Debreceni Jogi Múhely 2020. (XVII.) 3-4.

Debreceni Egyetem, Állam- és Jogtudományi Kar, Debrecen

(University of Debrecen, Faculty of Law, Debrecen)

DOI 10.24169/DJM/2020/3-4/2

culpa in contrahendo felelősségi alakzatra alapított igényt, melyet azzal indokolt a fórum, hogy az „Egyesmény e tekintetben kimeritö jellegü és meghaladja a nemzeti jogot”. Az Egyezmény a 4. Cikkben ugyanis szabályozza a szerződés megkötését, melynek elengedhetetlen feltétele az azt megelőző tárgyalások lefolytatása. ${ }^{56}$ Így a prekontraktuális felelősség kérdése az Egyezményben szabályozott ügy területén merül fel, ezáltal belső joghézag keletkezik, melynek kitöltésére pontos iránymutatást ad az Egyezmény. A 7. Cikk (2) bekezdése rögzíti, hogy az Egyezményben szabályozott ügyekkel összefüggő mindazokat a kérdéseket, amelyekre az Egyezmény kifejezett rendelkezést nem tartalmaz, elsődlegesen az Egyezmény alapjául szolgáló általános elvekkel összhangban kell megoldani. Ebben az esetben a kollíziós szabályok által kijelölt nemzeti jog csupán másodlagos szerepet tölt be, ${ }^{57}$ mivel a 7 . Cikk (1) bekezdése jogalapot nyújthat a szerződéskötést megelőző kártérítési felelősség megállapításához, ha a bíróságok úgy értelmezik a rendelkezést, hogy az a feleket jóhiszemú magatartásra kötelezi a tárgyalások folyamata alatt. ${ }^{58}$ A bíró szerepe ugyanis az Egyezmény értelmezésében nem korlátozott a szöveg szolgai követésére, sőt maga az Egyezmény is megkívánja, hogy egy dinamikus és kreatív célt kövessen, azaz általánosan elismert egy bizonyos fokú diszkrecionális joga, hogy a szabályokat a gyakorlat szükségeihez igazítsa. ${ }^{59}$ A jóhiszeműség követelményének alkalmazása ebben az esetben nem minősíthető az elv szükségtelen kiterjesztésnek, mivel az a szerződő felek viszonyában is joggal támasztható követelmény, ${ }^{60}$ és a nemzetközi kereskedelem stabil és kiszámítható múködéséhez elengedhetetlen, hogy a felek már a kontraktus megkötése előtt is olyan magatartást tanúsítsanak, amely összhangban áll a jóhiszeműség követelményével. ${ }^{61}$

A bomeward trend tendenciája figyelhető meg a stuttgarti Kerületi Bíróság által elbírált ügyben ${ }^{62}$ is. A német eladó és a magyar vevő adásvételi szerződést kötöttek egymással, melynek tárgya egy jelentôs értékű nyomtató gép volt. A vevő kifogásolta az áru minőségét és arra hivatkozott, hogy az nem áll összhangban a szerződésben meghatározott kritériumokkal, így 244.276 euró értékben perelte az eladót. Az alperes kérte a bíróságtól a felperes igényének elutasítását, valamint viszontkeresetként 14.696 euró kártérítést követelt, a gépen elvégzett javítási munkálatok miatt. A bíróság megállapította, hogy a jogvita elbírálása az Egyezmény hatálya alá tartozik. Ez alapján a vevőnek ésszerű határidőn belül értesítenie kellett az eladót a hibás teljesítésről az Egyezmény 39. Cikk (1) bekezdése értelmében. E tekintetben a bíróság megjegyezte, hogy „a joggyakorlat és a vezetố doktrína szerint az átlag körüllbelïl egy hónap”. Azonban mivel a hiba felfedezése és az erről szóló értesítés eladó részére történő megküldése között közel három hónap telt el, a bíróság elutasította a vevố kártérítési igényét. Az alperes ellenkövetelését viszont teljes egészében alaposnak találta. A bíróság bár helyesen állapította meg az Egyezmény alkalmazhatóságát, az alperes kárigényét az Egyezmény 74. Cikke helyett a Német Polgári Törvénykönyv (BGB) 632. szakasza alapján ítélte meg.

Hasonló probléma figyelhetô meg a $D$ \& Group v. H. A. Import63 ügyben is, amelyben a felek élelmiszeripari termékek adásvételéről szóló szerződést kötöttek egymással. Az eladó a megállapodásban meghatározott határidőn belül szállította az árut, azonban a vevő az átvétel után nem fizette meg a vételárat, és az áru visszaszolgáltatását sem ajánlotta fel. Az eladó pert indított a vevővel szemben, melynek keretén belül kártérítési igényt terjesztett elő az Egyezmény és az állami jog alapján is. A bíróság megállapította, hogy a jogvitát az Egyezmény szabályai szerint kell elbírálni, ugyanakkor a felperes állami jogra alapított kártérítési igényének is helyt adott, mivel „az az. Egyezményre alapitott igénnyel közös operativ tényekböl ered".

A fennmaradó két ügyben a bíróságok a jogvita eldöntése során kizárólag a nemzeti jog alapján elbírált

\footnotetext{
${ }^{56}$ KRITZER, Albert H.: Pre-Contract Formation; elérhető: http://www.cisg.law.pace.edu/cisg/biblio/kritzer1.html

${ }^{57}$ Hayward, Benjamin - Perlen, Patricia: The CISG in Australia - The Jigsaw Puzzle That Doesn't Quite Fit, Vindobona journal of international commercial law and arbitration, vol. 15., no. 1. pp. 119-156., 2011. 129.

${ }^{58}$ Goderre, Diane Madeline: International Negotiations Gone Sour: Precontractual Liability under the United Nations Sales Convention, 66 U. Cin. L. Rev. 257 (1997) 274.

${ }^{59}$ RAFFAI Katalin (szerk.): A nemzetközi gazdasági kapcsolatok a XXI. században - Ünnepi kötet a nyolcvanéves Bánrévy Gábor tiszteletére, Pázmány Press, Budapest (2011) 113.

60 SÁNDOR Tamás - VÉKÁs Lajos: i. m. 73.

${ }^{61}$ Spagnolo, Lisa: Opening Pandora's Box: Good Faith and Precontractual Liability in the CISG, 21 Temp. Int'l \& Comp. L. J. 261 (2007) 279.

62 Germany 15 October 2009 District Court Stuttgart (Printing Machine Case)

${ }^{63}$ United States 18 February 2015 District Court for the Southern District Court of New York (D \& G Group, S.R.I. v. H.A. Import USA)
} 
Debreceni Jogi Múhely 2020. (XVII.) 3-4.

Debreceni Egyetem, Állam- és Jogtudományi Kar, Debrecen

(University of Debrecen, Faculty of Law, Debrecen)

DOI 10.24169/DJM/2020/3-4/2

döntésekre utaltak, így értelmezve az Egyezmény rendelkezéseit. Az első ügy a Castel Electronics v. Toshiba Singapore ${ }^{64}$ eset, mely az Egyezmény egységes értelmezésének és alkalmazásának hiányát kiválóan szemlélteti. Ez az eset rávilágít továbbá arra a problémára is, hogy a bíróságok ítélkezésük során úgy veszik figyelembe a nemzeti jogot és az az alapján hozott döntéseket, hogy egyáltalán tudatában lennének annak, hogy ez ellentétes az Egyezmény koncepciójával. ${ }^{65}$ A Castel, mint ausztrál forgalmazó szerződést kötött meghatározott elektronikai cikkek adásvétele tekintetében a Toshiba szingapúri leányvállalatával. Az Ausztrál Szövetségi Bíróság által tárgyalt ügy legfőbb eldöntendő kérdése az volt, hogy a termékek megfelelnek-e a szerződésben foglaltaknak, és hogy a Castel jogosult-e a hibás teljesítésből eredő kártérítésre. A bíróság helyesen állapította meg, hogy ,mivel Ausztrália és Szingapúr az. Egyezmény részes államai, a CISG alkalmazandó. Ennek következtében a CISG szabályozza a felek szerzódésböl eredó jogait és kötelezettségeit, kizárva minden olyan müveletet, amelyröl az Ausztrál Adásvételi Törvény rendelkeęik." A szerződésszegés vonatkozásban a bíróság az Egyezmény 74. Cikke alapján kötelezte az alperest a felperes kárának megtérítésére, de a kártérítés tekintetében a fórum kizárólag nemzeti jogeseteket citáltt, ${ }^{66}$ így támasztva alá döntését. A bíróság lényegében figyelmen kívül hagyta az Egyezmény 7. Cikkét, mely különösen annak fényében ellentmondásos, hogy maga a fórum mondta ki az Egyezmény kizárólagos alkalmazását az ügyben, majd mégis a nemzeti Adásvételi Törvényre és annak joggyakorlatára támaszkodott.

Az ECEM v. Purolite ügyben ${ }^{67}$ a felek adásvételi szerződést kötöttek egymással, melynek tárgya sztirol volt, amely a víz és más folyadékok szennyeződéseinek eltávolításához szükséges termékek egyik alapvető alkotóeleme. A jogvita alapját az adta, hogy a Purolite társaság öt szállítmány sztirol után nem fizette meg az eladó részére a vételárat. Az Egyezmény 74. Cikkének értelmezése során a kulcskérdés a bizonyosság mértékére vonatkozott, amely ahhoz szükséges, hogy a felperes kártérítést követeljen. E tekintetben a bíróság nemzeti jogesetekre ${ }^{68}$ utalva megjegyezte, hogy „a károk csak akkor tekinthetöek távolinak vagy spekulativnak, ha a bizonytalanság a károk. fennállásának azonositása terén és nem a kár összegének vagy értékének. pontos kiszámitása tekintetében állapitható meg." További fontos kérdésként merült fel annak eldöntése, hogy a felperes általános költségei ${ }^{69}$ (overhead) megtéríthetók-e. A bíróság egy nemzeti jogesetre ${ }^{70}$ utalva, rögzítette, „hogy az általános këltségekeet a bruttó nyereség részeként kell keželni, és kárként meg kell itélni.”

\section{Összegzés}

Az esetjog revíziójának bizakodásra alapot adó megállapítása, hogy mindössze kilenc olyan döntés született a vizsgált időszakban, amikor a bíróság nemzeti kárfelelősségi doktrínát, jogintézményt, jogszabályt vagy joggyakorlatot alkalmazott a 74. Cikk értelmezése során. Azonban nyilvánvalóan ez sem segíti elő az egységesség megvalósítását. A nemzetközileg egységes adásvételi jog ugyanis csak egységes alkalmazás esetén válik valóra. Az Egyezmény értelmezéséhez ebből az a követelmény származik, hogy az egyezményes normákat esetleges nemzeti gyökerüktől elszakítva, autonóm módon kell felfogni és alkalmazni, ${ }^{71}$ nem szabad arra a definícióra támaszkodni, amelyet általában egy bizonyos jogintézményhez társítanak egy adott jogrendszer keretein belül. ${ }^{72}$ Az Egyezményt alkalmazó bíróságok számára követendő

\footnotetext{
${ }^{64}$ Australia 20 April 2011 Federal Court (Castel Electronics Pty Ltd. v. Toshiba Singapore Pte Ltd.)

${ }^{65}$ ZELLER, Bruno: The CISG and the Common Law: the Australian Experience In: Magnus, Ulrich (ed.): CISG vs. Regional Sales Law Unification - With a Focus on the New Common European Sales Law, Sellier European Law Publishers, Munich, (2012), 73.

${ }^{66}$ Commonwealth v. Cornwell; Playcorp Pty Ltd v. Taiyo Kogyo Ltd; Ginza Pte Ltd v. Vista Corp Pty Ltd

${ }^{67}$ United States 29 January 2010 Federal District Court [Pennsylvania] (ECEM European Chemical Marketing B. V.v. The Purolite Company)

${ }^{68}$ Carroll by Burbank v. Phila. Hous. Auth., 168 Pa. Commw. 275, 650 A.2d 1097, 1100 (Pa. Cmmw. Ct. 1994); Kituskie v. Corbman, 552 Pa. 275, 714 A.2d 1027, 1030 (Pa. 1998)

69 A pénzügyi szótár szerint olyan költség, amely egy vállalkozás fennálló üzleti kapcsolatából eredő folyamatos költségeire utal. Magában foglalja többek között a könyvelési, a biztosítási, a jogi, az utazási költségeket.

70 Vitex Mfg. Corp. v. Caribtex Corp., 377 F.2d 795, 798, 6 V.I. 166 (3d Cir. 1967.)

${ }^{71}$ SÁNDOR Tamás - VÉKÁs Lajos: i. m. 21.

${ }^{72}$ FERrari, Franco: CISG Case Law: A New Challenge for Interpreters? In: 17 Journal of Law and Commerce (1999) 245-261, 250.
} 
Debreceni Jogi Múhely 2020. (XVII.) 3-4.

Debreceni Egyetem, Állam- és Jogtudományi Kar, Debrecen

(University of Debrecen, Faculty of Law, Debrecen)

DOI 10.24169/DJM/2020/3-4/2

lehet a spanyol fuenlabradai fórum megállapítása, mely szerint „a nemzeti jog nem alkalmazható az Egyezmény által szabályozott ügyekben, és még értelmezési célból sem hivatkoz̧ható, mivel ez. ellentétes lenne az egységes alkalmazás elvével." "3

A feltárt jogi problémák rávilágítanak azokra a kérdésekre, amelyeknek az elbírálása nagyobb figyelmet követel meg a bíróságoktól, ezzel erősítve az Egyezmény univerzális jellegét, mely a nemzetközi, határokon átívelő kereskedelmi tranzakciókra is ösztönzőleg hathat, azáltal hogy kiszámíthatóbbá teszi a szerződésszegés következtében kialakuló diszfunkciók orvoslását.

\section{Irodalomjegyzék}

Bánrévy Gábor: A nemzetközi gazdasági kapcsolatok joga, 10. javított kiadás, Szent István Társulat, Budapest, 2018.,

Boros Sándor: Természetbeni teljesítés vagy kártérítés? Kontinentális és angolszász jogrendszeri válaszok, Debreceni Egyetem Állam- és Jogtudományi Kar, TDK-dolgozat, Debrecen, 2018.

Buschtöns, Corinna: Damages under the CISG: Selected Problems, School of Advanced Law of the University of Cape Town, 2005.

Csécsy Andrea: A szerződésszegés jogkövetkezményeinek magyar és külföldi összehasonlító jogi elemzése, PhD értekezés, Miskolci Egyetem Âllam- és Jogtudományi Kar, Deák Ferenc Állam- és Jogtudományi Doktori Iskola, Miskolc, 2008.

Efstathiou, Stefania: How internal and external gaps within the CISG are to be filled and an opinion on the approach taken by Art. 7. para 2

Ehlers, Andreas: Establishing a Uniform Interpretation of the CISG: A Case Study of Article 74, 2013 NJCL [v]

Ferrari, Franco: CISG Case Law: A New Challenge for Interpreters? In: 17 Journal of Law and Commerce (1999) p. 245-261

Ferrari, Franco: Comparative Ruminations on the Foreseeability of Damages in Contract Law, $53 \mathrm{La}$. L. Rev. 1993.

Glavanits Judit: A Bécsi Egyezmény magyar és nemzetközi joggyakorlata - kérdések és kétségek között In: Glavanits Judit (szerk.): A nemzetközi adásvételi szerződések joggyakorlatának aktuális kérdései, SZIE Deák Ferenc Állam- és Jogtudományi Kar, Győr, (2017)

Glavanits Judit - Rácz Diána: Szerződésszegő magatartások a Bécsi Vételi Egyezményben és az új Ptk.ban, Külgazdaság Jogi Melléklete, 2014. (5-6.) szám

Goderre, Diane Madeline: International Negotiations Gone Sour: Precontractual Liability under the United Nations Sales Convention, 66 U. Cin. L. Rev. 257, 1997.

Hayward, Benjamin - Perlen, Patricia: The CISG in Australia - The Jigsaw Puzzle That Doesn't Quite Fit, Vindobona journal of international commercial law and arbitration, vol. 15., no. 1. pp. 119-156., 2011.

Honnold, John O.: The Sales Convention in Action - Uniform International Words: Uniform Application? In: Journal of Law and Commerce, 1988., 207-212.

Huber, Peter - Mullis, Alastair: The CISG: A New Textbook for Students and Practitioners, Sellier European Law Publishers, Munich, 2007. https://doi.org/10.1515/9783866537286

Kirby, Amy A.: Punitive Damages in Contract Actions: The Tension between the United Nations Convention on Contracts for the International Sale of Goods and U. S. Law, 16 J. L. \& Com. 215, 1997.

Klein, John - Bachechi, Carla: Precontractual Liability and the Duty of Good Faith Negotiations in International Transactions, 17 Hous. J. Int'l L. 1, 1994.

\footnotetext{
${ }^{73}$ Spain 11 May 2012 Court of First Instance of Fuenlabrada (Production macbine for air conditioning ducts case)
} 
Debreceni Jogi Múhely 2020. (XVII.) 3-4.

Debreceni Egyetem, Állam- és Jogtudományi Kar, Debrecen

(University of Debrecen, Faculty of Law, Debrecen)

DOI 10.24169/DJM/2020/3-4/2

Kritzer, Albert H.: Pre-Contract Formation; http://www.cisg.law.pace.edu/cisg/biblio/kritzer1.html

Molnár István János: A nemzetközi gazdasági kapcsolatok joga II. - A nemzetközi gazdasági kapcsolatok magánjoga, 2. kiadás, Patrocinium, Budapest

Mádl Ferenc - Vékás Lajos: A nemzetközi magánjog és nemzetközi gazdasági kapcsolatok joga, ELTE Eötvös Kiadó, Budapest, 2012

Murphey, Arthur: Consequential Damages in Contracts for the International Sale of Goods and the Legacy of Hadley, 23 Geo. Wash. J. Int'l L. \& Econ. 415 (1989-1990)

Raffai Katalin (szerk.): A nemzetközi gazdasági kapcsolatok a XXI. században - Ünnepi kötet a nyolcvanéves Bánrévy Gábor tiszteletére, Pázmány Press, Budapest, 2011.

Sándor Tamás - Vékás Lajos: Nemzetközi Adásvétel: A Bécsi Egyezmény kommentárja, HVG-ORAC Lap- és Könyvkiadó, Budapest, 2005.

Spagnolo, Lisa: Opening Pandora's Box: Good Faith and Precontractual Liability in the CISG, 21 Temp. Int'l \& Comp. L. J. 261, 2007.

Szabó Sarolta: A Bécsi Vételi Egyezmény, mint nemzetközi lingua franca: Az egységes értelmezés és alkalmazás újabb irányai és eredményei, Pázmány Press, Budapest, 2014.

UNCITRAL: Digest of Case Law on the United Nations Convention on Contracts for the International Sale of Goods, Vienna, 2016.

Vékás Lajos: The Foreseeability Doctrine in Contractual Damage Cases In: Acta Juridica Hungarica 43, Nos 1-2, pp. 145-174, 2002. https://doi.org/10.1556/AJur.43.2002.1-2.8

Vörös Imre: A nemzetközi gazdasági kapcsolatok joga I., Krim Bt., Budapest, 2015.

Vörös Imre: A nemzetközi gazdasági kapcsolatok joga II., Krim Bt., Budapest, 2015.

Zeller, Bruno: The CISG and the Common Law: the Australian Experience In: Magnus, Ulrich (ed.): CISG vs. Regional Sales Law Unification - With a Focus on the New Common European Sales Law, Sellier European Law Publishers, Munich, 2012. 